This document was prepared in conjunction with work accomplished under Contract No. DE-AC09-96SR18500 with the U.S. Department of Energy.

This work was prepared under an agreement with and funded by the U.S. Government. Neither the U. S. Government or its employees, nor any of its contractors, subcontractors or their employees, makes any express or implied: 1 . warranty or assumes any legal liability for the accuracy, completeness, or for the use or results of such use of any information, product, or process disclosed; or 2 . representation that such use or results of such use would not infringe privately owned rights; or 3 . endorsement or recommendation of any specifically identified commercial product, process, or service. Any views and opinions of authors expressed in this work do not necessarily state or reflect those of the United States Government, or its contractors, or subcontractors. 


\title{
Relative Economic Incentives for Hydrogen from Nuclear, Renewable, and Fossil Energy Sources
}

\author{
Maximilian B. Gorensek ${ }^{\mathrm{a},}{ }^{*}$, Charles W. Forsberg ${ }^{\mathrm{b}}$ \\ ${ }^{a}$ Savannah River National Laboratory, Aiken, SC 29808 USA \\ ${ }^{\mathrm{b}}$ Department of Nuclear Science and Engineering, Massachusetts Institute of Technology, Cambridge, MA 02139 \\ USA
}

\begin{abstract}
The specific hydrogen market determines the value of hydrogen from different sources. Each hydrogen production technology has its own distinct characteristics. For example, steam reforming of natural gas produces only hydrogen. In contrast, nuclear and solar hydrogen production facilities produce hydrogen together with oxygen as a by-product or co-product. For a user who needs both oxygen and hydrogen, the value of hydrogen from nuclear and solar plants is higher than that from a fossil plant because "free" oxygen is produced as a by-product. Six factors that impact the relative economics of fossil, nuclear, and solar hydrogen production to the customer are identified: oxygen by-product, avoidance of carbon dioxide emissions, hydrogen transport costs, storage costs, availability of low-cost heat, and institutional factors. These factors imply that different hydrogen production technologies will be competitive in different markets and that the first markets for nuclear and solar hydrogen will be those markets in which they have a unique competitive advantage. These secondary economic factors are described and quantified in terms of dollars per kilogram of hydrogen.
\end{abstract}

Keywords: Hydrogen, Production, Economics, Nuclear, Renewable, Fossil, Comparison

\footnotetext{
${ }^{*}$ Corresponding author. Tel.: (803) 725-1314; Fax: (803) 725-8829;

E-mail address: maximilian.gorensek@srnl.doe.gov
} 


\section{Introduction}

Different methods of hydrogen production have different characteristics. Table 1 compares the characteristics of hydrogen produced by three dissimilar means: water-splitting using a high-temperature nuclear heat source (e.g. to drive a thermochemical cycle), steam reforming of coal, and water-splitting using decentralized solar energy (e.g. photovoltaic electricity coupled with electrolysis). The most economical choice depends on what the customer's needs are. Several important characteristics come into play.

- Hydrogen. If this is all that the customer needs, the economic comparison is based solely on the unit cost of hydrogen production.

- Oxygen. If the customer also needs oxygen, the oxygen is a "free" by-product of nuclear and solar hydrogen production. For such customers, the cost of an oxygen plant must be added to the cost of hydrogen if the hydrogen is to be produced from fossil fuels.

- Greenhouse gas emissions. If restrictions are imposed on the release of greenhouse gases to the atmosphere, either the cost of sequestering or disposing of the carbon dioxide, or the "carbon tax" penalty (if that is an option) should be added to the cost of hydrogen produced from fossil fuels.

- Transportation. Transportation costs for hydrogen strongly impact the relative costs of hydrogen from different sources. A customer who needs large quantities of hydrogen will need to add hydrogen transport costs to his centralized facility if the hydrogen is produced by dispersed renewable technologies. However, if the hydrogen is needed for decentralized applications, the cost of hydrogen transport will need to be added to that for centralized methods of hydrogen production. 
- Storage. The only proven low-cost method of hydrogen storage is in large underground reservoirs. If hydrogen storage is required by the customer, the cost of transporting hydrogen to the storage facility has to be included. This cost will be high for decentralized methods of hydrogen production.

- Heat. If the customer also needs heat, the cost of providing that heat needs to be considered. Nuclear plants should be able to provide heat at a lower cost than natural gas-fired heaters or furnaces. (This is certainly true for conventional nuclear plants. However, the advanced reactor designs that will most likely be used for hydrogen production have yet to be built so their economics are still open to debate.) Consequently, large consumers of both hydrogen and heat will have an incentive to buy hydrogen from nuclear production facilities so they can also take advantage of the simultaneous availability of low-cost heat.

- Institutional. Associated with every hydrogen production technology are specific institutional constraints that have economic implications.

Different markets also have differing requirements. Table 2 compares several possible applications for hydrogen on the basis of their requirements. In this example, the Xs in the table indicate where a match exists between the characteristics of nuclear hydrogen production and various markets [1]. Such tables provide a perspective on which markets are likely to be preferred for specific hydrogen production technologies. Similar tables can be constructed for any hydrogen production system to identify those markets where a specific hydrogen production technology will have a competitive advantage.

These markets have different characteristics. 
- Pipelines. Hydrogen pipelines deliver hydrogen to multiple customers from multiple producers in several parts of the world [2]. The pipeline owner is often the broker and the purchaser of the hydrogen. As pipeline networks grow, they will develop the characteristics of the electrical grid. In these systems hydrogen is a commodity market. This also means that the hydrogen production system is not tied to a specific hydrogen user facility. Consequently, the nuclear hydrogen plant operations (such as refueling) can be primarily determined by internal plant considerations rather than next-door-customer requirements.

- Chemical/Iron industries. Several types of chemical plants use massive quantities of hydrogen and could consume all of the hydrogen from a nuclear hydrogen plant. These include the production of ammonia and the extraction of iron from iron ore. The overwhelming characteristic of most of these markets is that there is a single customer with a single need: hydrogen. In such markets, centralized methods of hydrogen production are favored.

- Refineries. Refineries use massive quantities of hydrogen to remove sulfur from crude oil and to convert heavy oils to liquid fuels such as gasoline, diesel, and jet fuel. They also consume massive quantities of heat making them simultaneously potential markets for high-temperature heat. In fact, domestic refineries use over $7 \%$ of the total energy demand of the United States (U.S.) [3] and thus are a mega-market by themselves.

- Liquid fuels production. Plants using coal or biomass to produce liquid fuels require both hydrogen and oxygen. 
- Peak electric production. This market could use hydrogen, oxygen, and heat (to generate electricity on demand using fuel cells, high-temperature steam turbines, or other technologies). It is part of the same industry that produces base-load electricity from existing nuclear power plants. Consequently, it is also a market where nuclear energy is accepted.

The following sections examine each of the characteristics that impact the relative value of hydrogen in specific markets.

\section{Oxygen as a by-product}

Oxygen is a by-product of those hydrogen production methods that split water (e.g. water electrolysis, thermochemical cycles). This is the case for most nuclear and solar methods of hydrogen production. If there is a demand for oxygen, it becomes a second product for a hydrogen production plant. The cost of oxygen is a strong function of the price of electricity, because typical large cryogenic separation plants that separate oxygen from air consume about $220 \mathrm{kWh} /$ ton $\mathrm{O}_{2}\left(243 \mathrm{kWh} / \mathrm{t} \mathrm{O}_{2}\right)[4]$. At $\$ 0.04 / \mathrm{kWh}$, the energy costs total $\$ 8.80 /$ ton $\mathrm{O}_{2}(\$ 9.70 / \mathrm{t}$ $\mathrm{O}_{2}$ ). For the analysis herein, it is assumed that oxygen costs $\$ 20 /$ ton $(\$ 22 / \mathrm{t})$. On a mass basis, 8 times as much oxygen is produced as hydrogen. Consequently (assuming there is a demand), the value of the oxygen per kilogram of hydrogen produced is

$$
V_{O_{2}}=\left(\frac{\$ 22}{1 t O_{2}}\right)\left(\frac{1 t}{1,000 \mathrm{~kg}}\right)\left(\frac{8 \mathrm{~kg} \mathrm{O}}{1 \mathrm{~kg} \mathrm{H} H_{2}}\right)=\$ 0.176 / \mathrm{kg} \mathrm{H} \mathrm{H}_{2}
$$




\section{Avoidance of carbon dioxide releases}

Hydrogen today is produced primarily by steam reforming of fossil fuels, most often natural gas. The overall chemical reaction (for natural gas) is

$$
\mathrm{CH}_{4}+2 \mathrm{H}_{2} \mathrm{O} \rightarrow \mathrm{CO}_{2}+4 \mathrm{H}_{2} \text {. }
$$

Growing concerns about the effect of anthropogenic carbon dioxide on the global climate may eventually lead to the imposition of regulatory requirements for the disposal or geological sequestration of carbon dioxide, or to taxes or penalties being levied on the release of carbon dioxide to the atmosphere. A wide range of estimates have been proposed for possible future taxes on carbon dioxide releases to the atmosphere and for the cost of carbon dioxide sequestration. Low-end estimates indicate that taxes or sequestration costs could amount to $\$ 25 /$ ton $\mathrm{CO}_{2}\left(\$ 28 / \mathrm{tO}_{2}\right)[5]$.

The implications of adding a carbon dioxide tax or disposal cost of $\$ 25 / \mathrm{ton} \mathrm{CO}_{2}(\$ 28 / \mathrm{t}$ $\mathrm{CO}_{2}$ ) to the cost of hydrogen were calculated by assuming pure carbon is used for hydrogen production, i.e.

$$
\mathrm{C}+2 \mathrm{H}_{2} \mathrm{O} \rightarrow \mathrm{CO}_{2}+2 \mathrm{H}_{2}
$$

which is the worst-case scenario, and that the efficiency of converting carbon and water into hydrogen and carbon dioxide is $60 \%$. This would be analogous to steam reforming of coal, which is much more abundant than natural gas and is the most likely future fossil fuel hydrogen feedstock. The U.S. Department of Energy, Office of Fossil Energy (DOE-FE) cites 60\% conversion efficiency as its Hydrogen from Coal Program Central Production Pathway goal [6]. Input assumptions for the carbon penalty calculation are:

- Enthalpy of formation of water vapor: $\Delta_{\mathrm{f}} H^{\circ}=-241.826 \mathrm{~kJ} / \mathrm{gmol}[7]$ 
- Enthalpy of formation of carbon dioxide: $\Delta_{\mathrm{f}} H^{\circ}=-393.51 \mathrm{~kJ} / \mathrm{gmol}[7]$

- Energy efficiency in converting carbon to hydrogen: $60 \%$

The energy released by the combustion of enough carbon to make $1 \mathrm{t} \mathrm{CO}_{2}$ is

$$
\Delta H_{\text {combustion }}=\left(1 t \mathrm{CO}_{2}\right)\left(\frac{1,000 \mathrm{~kg}}{1 \mathrm{t}}\right)\left(\frac{1,000 \mathrm{~g}}{1 \mathrm{~kg}}\right)\left(\frac{12 \mathrm{~g} \mathrm{C}}{44 \mathrm{~g} \mathrm{CO}}\right)\left(\frac{1 \mathrm{gmol} \mathrm{C}}{12 \mathrm{~g} \mathrm{C}}\right)\left(\frac{393.51 \mathrm{~kJ}}{1 \mathrm{gmol} \mathrm{C}}\right)=8.94 \times 10^{6} \mathrm{~kJ}
$$

The energy equivalent of the hydrogen made by steam reforming enough carbon to make $1 \mathrm{t}$ $\mathrm{CO}_{2}$, taking into account the $60 \%$ conversion efficiency, is

$$
\Delta H_{H_{2}}=\left(8.94 \times 10^{6} \mathrm{~kJ}\right)(0.6)=5.37 \times 10^{6} \mathrm{~kJ} .
$$

The quantity of hydrogen produced from enough carbon to make $1 \mathrm{t}$ of $\mathrm{CO}_{2}$ follows from

$$
M_{\mathrm{H}_{2}}=\left(5.37 \times 10^{6} \mathrm{~kJ}\right)\left(\frac{1 \mathrm{gmol} \mathrm{H}_{2}}{241.826 \mathrm{~kJ}}\right)\left(\frac{2 \mathrm{~g} \mathrm{H}_{2}}{1 \mathrm{gmol} \mathrm{H}_{2}}\right)\left(\frac{1 \mathrm{~kg}}{1,000 \mathrm{~g}}\right)=44.4 \mathrm{~kg} \mathrm{H}_{2} .
$$

If there is a $\$ 25 /$ ton $\mathrm{CO}_{2}\left(\$ 28 / \mathrm{tCO}_{2}\right)$ disposal cost, the cost impact on hydrogen, if the hydrogen is produced from carbon, is

$$
C_{\mathrm{CO}_{2}}=\left(\frac{\$ 28}{1 t \mathrm{CO}_{2}}\right)\left(\frac{1 t \mathrm{CO}_{2}}{44.4 \mathrm{~kg} \mathrm{H} \mathrm{H}_{2}}\right)=\$ 0.63 / \mathrm{kg} \mathrm{H}
$$

Therefore, constraints on greenhouse gas emissions have the potential to significantly alter the economics of hydrogen production from fossil fuels when compared to hydrogen production by other, greenhouse gas emission-free methods.

\section{Hydrogen transport}

Hydrogen transportation by pipeline is expensive. Over any distance such transport can easily add $\$ 1.00 / \mathrm{kg} \mathrm{H}_{2}$ or more to the cost of hydrogen. Consequently, for large, localized users, 
strong incentives exist to use centralized production of hydrogen to meet those needs to avoid the transport costs. The exact benefit or cost is dependent upon the specific case.

A number of commercial hydrogen pipelines that service a number of chemical users are currently in operation in the U.S. Gulf Coast area and in Northern Europe [2]. Their lengths range from less than a mile (about a kilometer) to several hundred miles (hundreds of kilometers). Refineries are the largest users of imported hydrogen, at about 50 MMSCFD $\left(1.3 \times 10^{6} \mathrm{Nm}^{3} / \mathrm{d}\right)$, while chemical plants typically use less than $10 \mathrm{MMSCFD}\left(0.3 \times 10^{6} \mathrm{Nm}^{3} / \mathrm{d}\right)$, with the exception of those producing ammonia and methanol.

The cost of hydrogen transport by pipelines of different sizes carrying different quantities of gas is shown in Table 3 [8]. The investment and operating cost of pipeline compressors is also shown. Hydrogen has the lowest possible molecular weight so reciprocating compressors are typically used regardless of the size of the pipeline, although oil-flooded screw compressors have begun to be used as well [9].

Specific constraints are associated with fossil and solar hydrogen production. Because of the cost of hydrogen transport, restrictions on greenhouse gas releases could significantly alter the economics of hydrogen production from fossil fuels compared to other primary energy sources. Multiple projects are under way to develop methods to produce hydrogen from fossil fuels with subsequent underground injection of the carbon dioxide by-product. However, only parts of the U.S. have geologies suitable for such sequestration. Hydrogen made from fossil fuels with carbon dioxide sequestration may have the lowest production costs in cases where fossil fuels and sequestration sites are located in close proximity. However, hydrogen made from fossil fuels with carbon sequestration will have higher delivered costs elsewhere because of the cost of transporting the hydrogen by pipeline. 
Hydrogen from renewable energy sources faces similar geographical constraints. Unlike nuclear energy, the cost and availability of renewable energy sources are strongly dependent on location. Solar-based systems are most economic in the sunny southwest U.S. Wind resources are most abundant on the upper Great Plains (North Dakota, Montana, South Dakota, Minnesota, etc.) and in coastal areas. There is a second factor - solar hydrogen systems are being developed for local hydrogen production and use. These small-scale systems for small users are designed to avoid transport costs.

\section{Hydrogen storage}

Only one technology currently exists for low-cost storage of hydrogen — storage underground in caverns or geological reservoirs [10]. This is the same technology used to store natural gas. In the U.S., natural gas is moved by pipeline throughout the year to northern markets from production areas in the south-central U.S. The natural gas is stored in about 400 large facilities, with a total capacity to store a third of a year's production of natural gas [11]. Underground storage is a low-cost technology with market prices for storage ranging from $\$ 0.40$ to $\$ 1.00 /$ MMBtu $(\$ 0.38$ to $\$ 0.95 / \mathrm{GJ})$, which is on the order of $10 \%$ of the value of the natural gas [12].

Commercial hydrogen storage facilities using this technology have been built in the U.S. (e.g. ConocoPhillips/ChevronPhillips' Clemens Terminal facility and Praxair's Moss Bluff Storage Facility, both in Texas) and in Europe (e.g. ICI Teeside facility in England). For hydrogen, the storage costs for such facilities are estimated to be $\$ 0.10-\$ 1.20 / \mathrm{kg}[13,14]$, depending to some extent on residence time, which is lower than the production cost for 
hydrogen. The hydrogen storage technology has been used commercially in several geologies but not yet demonstrated in all the geologies that have been used for natural gas.

Storage economics demand large facilities. Two factors drive the facility size. First are siting and site development costs (including understanding the local geology) that are almost independent of facility capacity. Second, gas storage requires compression of the gases, typically to pressures of $\sim 1000$ psi ( $\sim 70$ bar) for storage. Gas equipment efficiencies and costs are strong functions of the size of the equipment. The practical implication is that if bulk hydrogen storage is required by the customer, strong incentives exist for large-scale centralized hydrogen production to avoid hydrogen collection costs from decentralized hydrogen production facilities.

\section{Low-cost heat}

Many industrial applications of hydrogen also require process heat. As will be shown below, the cost of heat produced by nuclear plants is far less than that from natural gas combustion (typically $\$ 6.00$ to $\$ 11.00 / \mathrm{MMBtu}$, or $\$ 5.70$ to $\$ 10.40 / \mathrm{GJ}$ ) and, in much of the U.S., less than heat from burning coal. This difference will only grow with time. The price of natural gas is unpredictable in the near term because of tight supply and the potential for rapid swings in demand due to changes in weather or other key factors. Over the long run, however, it has kept pace with the price of crude oil on a $\$ / M M B t u$ or $\$ /$ GJ basis [15]. Furthermore, there is an increased likelihood that natural gas prices will ultimately approach oil prices. Oil has a world price because it is inexpensive to transport around the world. With the growth of liquefied natural gas (LNG) moved by sea, there will be increasingly a world natural gas price that approaches oil prices and is tied to world oil prices by users that can burn oil or gas. 
Consequently, as oil production declines and the price of oil increases, so will the price of natural gas and the cost of natural gas heat.

If hydrogen is being produced for an industrial hydrogen consumer sitting across the fence from a nuclear-hydrogen plant, process heat can also be sold. The manner in which the heat is delivered depends upon the required temperature. For temperatures below $600^{\circ} \mathrm{C}$, the heat will most likely be delivered as steam, because this is the standard, proven industrial technology for transferring heat to industrial facilities. At higher temperatures, helium or molten salts may be used to transfer heat.

The price of nuclear plant heat can be estimated from the price of electricity. A nuclear power plant produces steam that can be sold or used to produce electricity. The utility will demand at least the same revenue from the sale of steam as from the sale of electricity. A rough estimate of the price of steam can be calculated from the wholesale price of electricity. The price depends upon the temperature and pressure of the steam because more electricity can be made from high-temperature, high-pressure steam than from low-temperature, low-pressure steam.

An example can clarify this. Because the technology is well defined, the sale of steam from a light water reactor (LWR) will be used. Once the parameters of a high-temperature reactor are defined, similar calculations can be done. Consider the sale of 150-psi (10-bar) steam $\left(\sim 180^{\circ} \mathrm{C}\right.$, or $\left.\sim 450 \mathrm{~K}\right)$ used for general heating and many industrial processes — including drying of many products and production of fuel ethanol. The price of electricity varies across the country. This example uses the average market price for wholesale electricity on the Cinergy trading hub in Ohio during the first three months of 2008 , which is $\$ 58.25 / \mathrm{MWh}_{\mathrm{e}}[16]$.

The efficiency of LWR power plants is $\sim 33 \%$. That means if one less $\mathrm{J}_{\mathrm{e}}$ of electricity is produced, $3 \mathrm{~J}_{\text {th }}$ of steam becomes available. Although nuclear reactors produce high-temperature 
steam, in this example the heat is delivered as 150-psi (10-bar) steam. In converting high temperature steam to electricity, about $40 \%$ of the electricity is obtained by the time the steam pressure drops to 150 psi (10 bar), with the remaining $60 \%$ of the electricity produced in the lowpressure turbines. Using this information, a rough estimate can be made of the corresponding price of steam from a nuclear plant, given the price of electricity:

$$
V_{\text {heat }}=\left(\frac{\$ 58.25}{1 M W h_{e}}\right)\left(\frac{1 M W h_{e}}{3 M W h_{t h}}\right)\left(\frac{1,000 M W h_{t h}}{1 G W h_{t h}}\right)\left(\frac{1 h}{3,600 \mathrm{~s}}\right) \times 0.6=\$ 3.24 / G J(\$ 3.41 / M M B t u) \text {. }
$$

This cost represents less than half the price of natural gas in the U.S. Therefore, if a customer needs both hydrogen and process heat, there is an incentive to obtain the hydrogen from a nuclear plant if, at the same time, the customer can obtain lower cost heat to meet his energy needs. One caveat that should be kept in mind is that this nuclear process heat cost estimate is based on LWR economics, whereas nuclear hydrogen production processes will use advanced reactor designs for which there are no commercial capital and operating cost data. However, it is reasonable to expect that their costs will be comparable and not much higher, otherwise there would be no incentive to build them.

\section{Institutional}

All industries have institutional structures that include regulation, organizational structures, international trade agreements, and accepted business practices for that industry. These structures have major impacts on the choice of hydrogen production technology. Two examples provide a perspective on the extremes of these institutional structures.

- Peak electric power production [17]. Assuming that the technology and economics are favorable, the institutional structure for using nuclear hydrogen for peak electrical power 
is highly favorable. Nuclear power plants are built to produce base-load electricity. The production of peak electricity is an extension of that business by organizations that understand nuclear energy, operate nuclear power plants, and sell electricity. In such cases, the producer of hydrogen is also the user of hydrogen. Consequently, the market is not an issue. Furthermore, the market for peak power is local. What happens in the rest of the world has only limited impact on the local peak power demand. There is also a second institutional factor. In the U.S. about half the utilities are regulated utilities with access to low-cost financing. This institutional structure favors high-capital-cost, lowoperating-cost power systems - characteristics that would match nuclear hydrogen generation for peak power.

- Ammonia production. The cost of ammonia production is primarily based on the cost of hydrogen, so economics are heavily dependent upon hydrogen production costs. However, ammonia is transported by ship around the world and, in the U.S., by pipeline from Louisiana as far north as Minnesota. The price of ammonia is set on a global basis. New ammonia plants are built wherever there is low-cost natural gas that has no local market (e.g. Trinidad). Over the course of a decade, the lowest cost natural gas in the world can strongly impact the cost of ammonia world-wide. Governments can push ammonia production and drive down world prices to encourage local development. This is an institutional structure that potentially makes it risky to invest in capital-intensive technologies such as nuclear-hydrogen for ammonia production. 


\section{Conclusions}

Different methods of hydrogen production have different characteristics, while different markets have differing requirements. Six characteristics were identified and discussed that impact the relative value of hydrogen produced by different methods in specific markets. These are: oxygen as a by-product, avoidance of carbon dioxide releases, hydrogen transport, hydrogen storage, availability of low-cost heat, and institutional factors. Four of these characteristics are quantifiable in terms of their direct impact on hydrogen cost, which is summarized in Table 4. Nuclear hydrogen production plants will be capable of co-generating process heat at a significant discount compared to heat from fossil fuel combustion, particularly natural gas, which may be advantageous in some markets. Finally, institutional structures, including regulation, organizational structures, international trade agreements, and business practices may also strongly influence the choice of hydrogen production technology.

User requirements will ultimately determine the preferred method of hydrogen production. Because user requirements vary widely, it is likely that different hydrogen production techniques will be economic for different users. This also implies that for any new hydrogen production technology, there are specific markets in which that technology is most likely to become competitive relative to other production techniques.

\section{Acknowledgements}

This work was performed under DOE Contract Nos. DE-AC05-00OR22725 (at Oak Ridge National Laboratory) and DE-AC09-96SR18500 (at Savannah River National Laboratory). Funding was provided by DOE-NE under the NHI program. Mr. Carl Sink was the program manager. 


\section{References}

1 Forsberg CW. Competitive-Advantage Markets for Hydrogen from Nuclear Energy: Peak Electric Power, Liquid Fuels from Coal and Biomass, and Refineries. Oak Ridge National Laboratory (in press).

2 Baade WF, Parekh UN, and Raman V. Hydrogen. in Seidel A, ed. Kirk-Othmer Encyclopedia of Chemical Technology $-5^{\text {th }}$ ed., Vol. 13. New York: John Wiley \& Sons, Inc., 759-808 2005. 3 Petroleum Industry Analysis Briefs: Energy Consumption. Energy Information Administration. Jan 28, 2004.

http://www.eia.doe.gov/emeu/mecs/iab98/petroleum/energy use.html, accessed July 17, 2008.

4 Ochs TL, Oryshchyn DL, Ciferno JP, Summers C. Ranking of Enabling Technologies for Oxy-Fuel Based Carbon Capture. Proc $32^{\text {nd }}$ Int Tech Conf on Coal Utiliz \& Fuel Systems, Clearwater, FL, Jun 10-15, 2007:31-42.

5 Deutch J and Moniz EJ (co-chairs). The Future of Coal; Options for a Carbon-Constrained World. Cambridge, MA: Massachusetts Institute of Technology, 2007. http://web.mit.edu/coal/The_Future_of_Coal.pdf, accessed April 29, 2008.

6 US Department of Energy, Office of Fossil Energy. Hydrogen from Coal Program; Research, Development, and Demonstration Plan for the Period 2007 through 2016. Washington, DC, September 2007.

7 Cox JD, Wagman DD, Medvedev VA. CODATA Key Values for Thermodynamics. New York: Hemisphere Publishing Corp., 1984:1.

8 Summers WA. Centralized Hydrogen Production from Nuclear Power: Infrastructure Analysis and Test-Case Design Study, NERI Project 02-160, Interim Project Report, Task A.1, 
Nuclear Hydrogen Plant Definition, WSRC-TR-2003-00484, Savannah River Technology Center, October 30, 2003. http://www.energetics.com/neri/index/NERI_02-160_AR_FY03.pdf, accessed April 29, 2008.

9 Ohama T, Kurioka Y, Tanaka H, Koga T. Process Gas Applications where API 619 Screw Compressors Replaced Reciprocating and Centrifugal Compressors. Proceedings of the $35^{\text {th }}$ Turbomachinery Symposium, Houston, TX, Sept 26-28, 2006 89-96. http://www.turbomachinerymag.com/white\%20papers/Screw\%20compressors.pdf accessed July $17,2008$.

10 Forsberg CW. Is Hydrogen the Future of Nuclear Energy? Proceedings, International Topical Meeting on Safety and Technology of Nuclear Hydrogen Production, Control, and Management, American Nuclear Society, Boston, MA, June 24-28, 2007 18-24.

11 US Department of Energy, Energy Information Administration. The Basics of Underground Natural Gas Storage. August 2004.

http://www.eia.doe.gov/pub/oil gas/natural gas/analysis publications/storagebasics/storagebasic

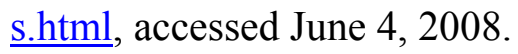

12 Dietert JA, Pursell DA. Underground Natural Gas Storage. Houston, TX: Simmons \& Company International, Energy Industry Research.June 28, 2000. www.simmonscointl.com/files/63.pdf, accessed June 4, 2008.

13 Tsimas E, Filiou C, Peteves SD, and Veyret J-B. Hydrogen Storage: State-of-the-Art and Future Perspective. European Commission, Directorate General, Joint Research Centre, Institute for Energy, Petten, The Netherlands, EUR 20995/EN (2003). 
14 Padró CEG, Putsche V. Survey of the Economics of Hydrogen Technologies. Golden, CO: National Renewable Energy Laboratory, NREL/TP-570-27079, Sept 1999.

http://www1.eere.energy.gov/hydrogenandfuelcells/pdfs/27079.pdf, accessed July 17, 2008. 15 US Department of Energy, Energy Information Administration. Annual Energy Review 2007. DOE/EIA-0384(2007). Washington, DC: US Government Printing Office, June 2008 64-5. 16 US Department of Energy, Energy Information Administration. Intercontinental Exchange (ICE) / Wholesale. March 25, 2008.

http://www.eia.doe.gov/cneaf/electricity/wholesale/wholesale.html, accessed June 4, 2008.

17 Forsberg CW. Economics of Meeting Peak Electricity Demand Using Nuclear Hydrogen and Oxygen. Proceedings, International Topical Meeting on Safety and Technology of Nuclear Hydrogen Production, Control, and Management, American Nuclear Society, Boston, MA, June 24-28, 2007 40-50. 
Table 1

Characteristics of different methods of hydrogen production

\begin{tabular}{lcccccc}
\hline Production Method & $\mathrm{O}_{2}$ & $\begin{array}{c}\mathrm{CO}_{2-} \\
\text { Free }\end{array}$ & $\begin{array}{c}\text { Large- } \\
\text { Scale Use }\end{array}$ & $\begin{array}{c}\text { Bulk } \\
\text { Storage }\end{array}$ & $\begin{array}{c}\text { Low-Cost } \\
\text { Heat }\end{array}$ & Institutional \\
\hline Nuclear & $\mathrm{X}$ & $\mathrm{X}$ & $\mathrm{X}$ & $\mathrm{X}$ & $\mathrm{X}$ & $?$ \\
Steam Reforming of Coal & & & $\mathrm{X}$ & $\mathrm{X}$ & & $?$ \\
Decentralized Solar & $\mathrm{X}$ & $\mathrm{X}$ & & & & $?$ \\
\hline
\end{tabular}


Table 2

Characteristics and value $(\mathrm{X})$ of nuclear hydrogen relative to other methods of hydrogen production for specific applications

\begin{tabular}{lcccccc}
\hline Application & $\mathrm{O}_{2}$ & $\begin{array}{c}\mathrm{CO}^{2} \\
\text { Free }\end{array}$ & $\begin{array}{c}\text { Large- } \\
\text { Scale Use }\end{array}$ & $\begin{array}{c}\text { Bulk } \\
\text { Storage }\end{array}$ & $\begin{array}{c}\text { Low-Cost } \\
\text { Heat }\end{array}$ & Institutional \\
\hline Small Local User & & $\mathrm{X}$ & & & & \\
Pipeline & & $\mathrm{X}$ & $\mathrm{X}$ & & & \\
Chemical/Iron Industries & & $\mathrm{X}$ & $\mathrm{X}$ & & $\mathrm{X}$ & \\
Refinery & $?$ & $\mathrm{X}$ & $\mathrm{X}$ & $?$ & $\mathrm{X}$ & \\
Liquid Fuels Production & $\mathrm{X}$ & $\mathrm{X}$ & $\mathrm{X}$ & $?$ & $\mathrm{X}$ & \\
Peak Electric Production & $\mathrm{X}$ & $\mathrm{X}$ & $\mathrm{X}$ & $\mathrm{X}$ & $\mathrm{X}$ & $\mathrm{X}$ \\
\hline
\end{tabular}


Table 3

Cost of hydrogen transport by pipeline, adapted from [8]

\begin{tabular}{cccccc}
\hline $\begin{array}{c}\mathrm{H}_{2} \mathrm{Gas} \\
\text { Capacity, } \\
10^{6} \mathrm{Nm}^{3} / \mathrm{d}\end{array}$ & $\begin{array}{c}\text { Line } \\
\text { Size, in } \\
(\mathrm{cm})\end{array}$ & $\begin{array}{c}\text { Pipeline } \\
\text { Investment, } \\
\$ \mathrm{M} / 100 \mathrm{~km}\end{array}$ & $\begin{array}{c}\text { Compression } \\
\text { Investment, } \\
\mathbf{\$ M} / 100 \mathrm{~km}\end{array}$ & $\begin{array}{c}\text { Compression } \\
\text { Power Cost, } \\
\$ / \text { day }\end{array}$ & $\begin{array}{c}\text { Pipeline } \\
\text { Cost/100 km, } \\
\$ / \mathrm{kg} \mathrm{HHV}\end{array}$ \\
\hline 19.8 & $20(50.8)$ & 93,000 & 20,500 & 20,300 & 0.042 \\
13.1 & $16(40.6)$ & 79,000 & 18,500 & 18,300 & 0.054 \\
7.2 & $12(30.5)$ & 65,000 & 13,300 & 13,200 & 0.078 \\
2.9 & $8(20.3)$ & 52,000 & 7,500 & 7,000 & 0.138 \\
0.86 & $4(10.2)$ & 39,000 & 7,800 & 7,200 & 0.386
\end{tabular}


Table 4

Impact of characteristics on hydrogen cost

\begin{tabular}{lcc}
\hline Factor & Potential Cost Impact, & Consequence \\
\hline Oxygen as a By-product & $\$ / \mathrm{kg} \mathrm{H}_{2}$ & Nuclear and Solar Gain \\
Carbon Dioxide Releases & -0.18 & Fossil Penalty \\
Hydrogen Transport & 0.63 & Incentive for Production to Match User \\
Hydrogen Storage & $>1.00$ & For Centralized Storage \\
\hline
\end{tabular}

